\title{
Outdoor Thermal Comfort Optimization through Vegetation Parameterization: Species and Tree Layout
}

\author{
Bouthaina Sayad ${ }^{1}$, Djamel Alkama ${ }^{2}\left(\mathbb{D}\right.$, Redha Rebhi ${ }^{3,4}$, Younes Menni ${ }^{5}\left(\mathbb{D}\right.$, Hijaz Ahmad $^{6,7, *(\mathbb{D} \text {, }}$ \\ Mustafa Inc 8,9,10,*(D), Mohsen Sharifpur 10,11,12,*(D), Giulio Lorenzini 13,*(D), Ehab Azab 14 (D) \\ and Ashraf Y. Elnaggar 14
}

Citation: Sayad, B.; Alkama, D.; Rebhi, R.; Menni, Y.; Ahmad, H.; Inc, M.; Sharifpur, M.; Lorenzini, G.; Azab, E.; Elnaggar, A.Y. Outdoor Thermal Comfort Optimization through Vegetation Parameterization: Species and Tree Layout. Sustainability 2021 13, 11791. https://doi.org/10.3390/ su132111791

\section{Academic Editors:}

Amir Ebrahimi-Moghadam and Mohammad Hossein Ahmadi

Received: 17 September 2021

Accepted: 14 October 2021

Published: 25 October 2021

Publisher's Note: MDPI stays neutral with regard to jurisdictional claims in published maps and institutional affiliations.

Copyright: (C) 2021 by the authors Licensee MDPI, Basel, Switzerland. This article is an open access article distributed under the terms and conditions of the Creative Commons Attribution (CC BY) license (https:/ / creativecommons.org/licenses/by/ $4.0 /)$.
1 Civil Engineering and Hydraulics Laboratory, University 8 Mai 1945 Guelma, Guelma 24000, Algeria; bouthaina41@hotmail.com

2 Department of Architecture, University 8 Mai 1945-Guelma, Guelma 24000, Algeria; dj.alkama@gmail.com

3 Department of Mechanical Engineering, Faculty of Technology, University of Medea, Medea 26000, Algeria; rere.univ26000@gmail.com

4 LERM-Renewable Energy and Materials Laboratory, University of Medea, Medea 26000, Algeria

5 Department of Technology, University Centre of Naama, P.O. Box 66, Naama 45000, Algeria; menni.younes@cuniv-naama.dz

6 Mathematics in Applied Sciences and Engineering Research Group, Scientific Research Center, Al-Ayen University, Nasiriyah 64001, Iraq

7 Section of Mathematics, International Telematic University Uninettuno, Corso Vittorio Emanuele II, 39, 00186 Roma, Italy

8 Department of Computer Engineering, Biruni University, Istanbul 34025, Turkey

9 Department of Mathematics, Science Faculty, Firat University, Elazig 23119, Turkey

10 Department of Medical Research, China Medical University Hospital, China Medical University, Taichung 404, Taiwan

11 Department of Mechanical and Aeronautical Engineering, University of Pretoria, Pretoria 0002, South Africa

12 Department of Mechanical Engineering, University of Science and Culture, Tehran 1461968151, Iran

13 Department of Engineering and Architecture, University of Parma, Parco Area delle Scienze, 181/A, 43124 Parma, Italy

14 Department of Food Science and Nutrition (Previously Chemistry), College of Sciences, Taif University, P.O. Box 11099, Taif 21944, Saudi Arabia; e.azab@tu.edu.sa (E.A.); aynaggar@tu.edu.sa (A.Y.E.)

* Correspondence: hijaz555@gmail.com (H.A.); minc@firat.edu.tr (M.I.); mohsen.sharifpur@up.ac.za (M.S.); giulio.lorenzini@unipr.it (G.L.)

Abstract: The optimization of outdoor thermal comfort has become the keystone to guarantee the healthy and comfortable use of outdoor spaces. This study aims to optimize the outdoor thermal comfort through vegetation parameterization in a boulevard located in Guelma city, Algeria during summertime. However, two main parameters were investigated, species and tree layout, through a numerical simulation. We first collected microclimate data of a sunny summer day. Second, we used real microclimate data in different simulations using the Envi-met atmospheric model. The findings reveal that Ficus Nitida is the most significant species to intercept solar radiation and provide shade over the day in Souidani Boudjemaa Boulevard, with a maximum reduction of $\mathrm{T}_{\mathrm{a}}=0.3{ }^{\circ} \mathrm{C}$ and $\mathrm{UTCI}=2.6^{\circ} \mathrm{C}$ at 13:00 p.m. Tree layout is a determining parameter in the creation of shaded paths, based on the quality of the shadows cast by the trees, namely, their size. Thereby, planting the washingtonia palm trees along the center of the boulevard is the best option to maximize the shaded area within the boulevard, with maximum reduction of $\mathrm{T}_{\mathrm{a}}=1.8^{\circ} \mathrm{C}$ and $\mathrm{UTCI}=3.5^{\circ} \mathrm{C}$ at $16: 00$ p.m.

Keywords: outdoor thermal comfort; vegetation parameterization; tree species; tree layout; summertime; optimization; numerical simulation

\section{Introduction}

Today, over $55 \%$ of the world's population lives in urban areas, a percentage that is expected to increase to $68 \%$ by 2050 [1]. In addition to this problematic, current cities are 
facing the issue of climate change, such as the Urban Heat Island (UHI) phenomenon [2]. In case of being out of control, extremely hot and overstretched cities with high community residents are going to be born. Outdoor spaces' quality through various functions, such as thermal, hygienic, functionality, aesthetic, and safety functions, is the primary factor influencing the community residents' life quality $[3,4]$. More attention has recently been paid to outdoor thermal comfort in order to combat the UHI problem and create comfortable outdoor areas [5-7]. Thermal conditions outdoors are likely to experience enormous upheavals in built up areas due to the effect of human-induced climate change, including the increased temperatures and the heat weaves in summertime [8-10]. As a result of these facts, a variety of sciences have been gathered in order to enhance the urban microclimate and maximize thermal comfort in outdoor places [11-13]. Hence, a variety of mitigation and adaptation strategies have been created, such as urban vegetation, urban geometry, and high albedo materials [14-16]. Moreover, much interest is associated to nature-based solutions to optimize the thermal comfort levels in urban outdoor spaces [17-19]. The role of vegetation is much more attributable in improving the thermal comfort in outdoor spaces, both as a strategy for adapting to the thermal environment at the pedestrian level and as a strategy for mitigating climate change effects [20-22]. Trees, on the other hand, are the most effective features in terms of microclimatic control and enhancing thermal comfort levels during the hot summer months due to their impact [23,24]. Previous studies have shown that the ratio (number of trees) and the tree layout are two parameters influencing the shading effect outdoors $[25,26]$. The relationship between the vegetation cover of outdoor spaces and thermal comfort levels finds a very precise modeling in atmospheric simulation models $[27,28]$. These models have the benefit of being able to replicate smaller spatial scales, as well as recreating the transmission processes of microclimatic factors and their impacts on pedestrians using thermal and climatic indices such as the UTCI, PET (Physiological Equivalent Temperature), SET (Standard Effective Temperature), and PMV (Predicted Mean Vote) indices [29,30]. Other studies have modeled the energy consumption of high-rise office buildings in hot, arid, and cold climate conditions in many buildings [31-35].

Our study aims to optimize the outdoor thermal comfort through vegetation parameterization in a boulevard located in Guelma city, Algeria during summertime. However, two main parameters were investigated, species and tree layout, through a numerical simulation. Microclimatic changes are studied using the output data from the several simulations: air temperature $\left(T_{a}\right)$, relative humidity $(R H)$, mean radiant temperature $\left(T_{m r t}\right)$, and wind velocity $\left(\mathrm{V}_{\mathrm{a}}\right)$. In each situation, the UTCI thermal index (Universal Thermal Climate Index) is utilized to determine the level of climatic comfort.

\section{Case Study}

This research was conducted in Guelma, a city located $65 \mathrm{~km}$ from the Mediterranean Sea in northeastern Algeria ( $36^{\circ} 27^{\prime} 43 \mathrm{~N} ; 7^{\circ} 25^{\prime} 33 \mathrm{E} ; 840 \mathrm{ft}$. elevation), as represented in Figure 1a,b. Its climate is classified as semi-arid, according to Belda et al. [36]. Guelma has a longer and hotter summer than the rest of the country, with frequent heat waves. The warmest days of the year are generally between July and mid-August.

Souidani Boudjemaa Boulevard, in the city's downtown, is the study area. It is a 485-m-long linear outdoor space with two mechanical lanes, two pedestrian pathways on its edges, and a center reservation with Ficus trees on both sides. The southwest aisle is entirely devoid of vegetation, unlike the northeast aisle, which is armed with dense old Ficus trees, Figure 1c. 


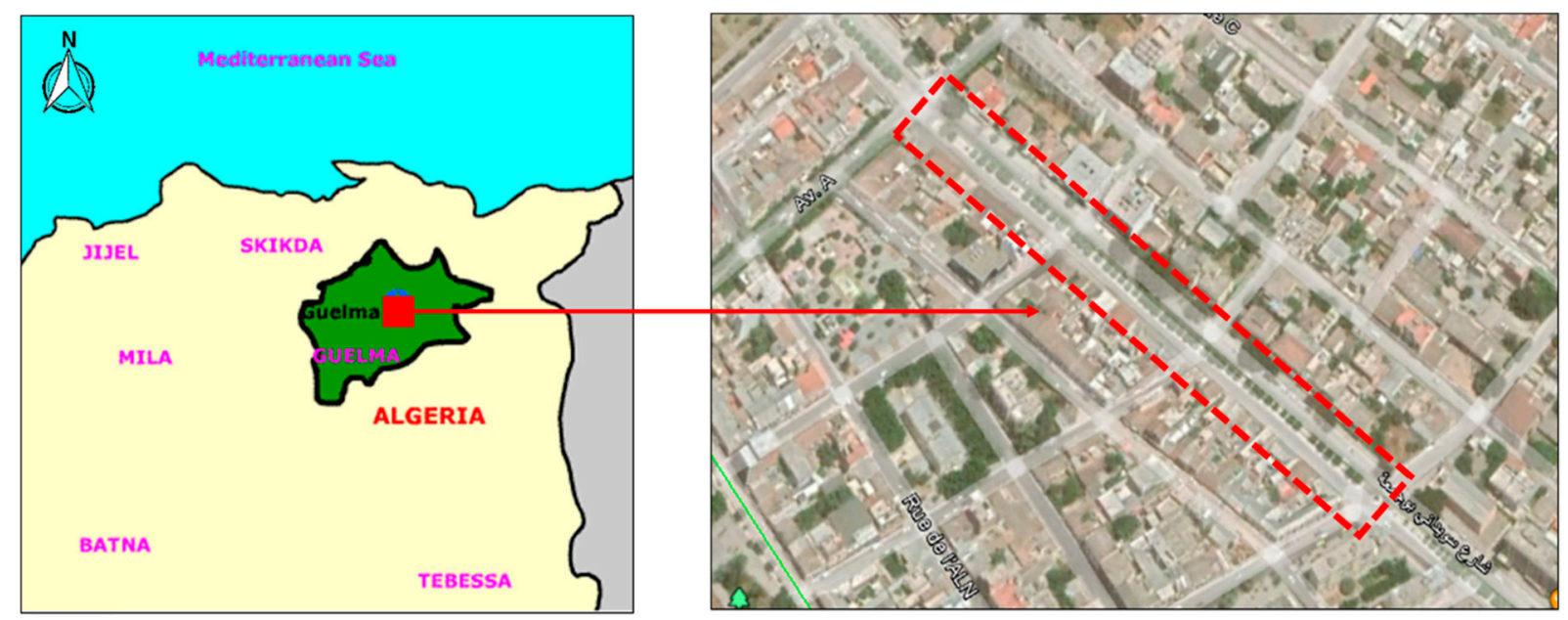

(a)

(b)

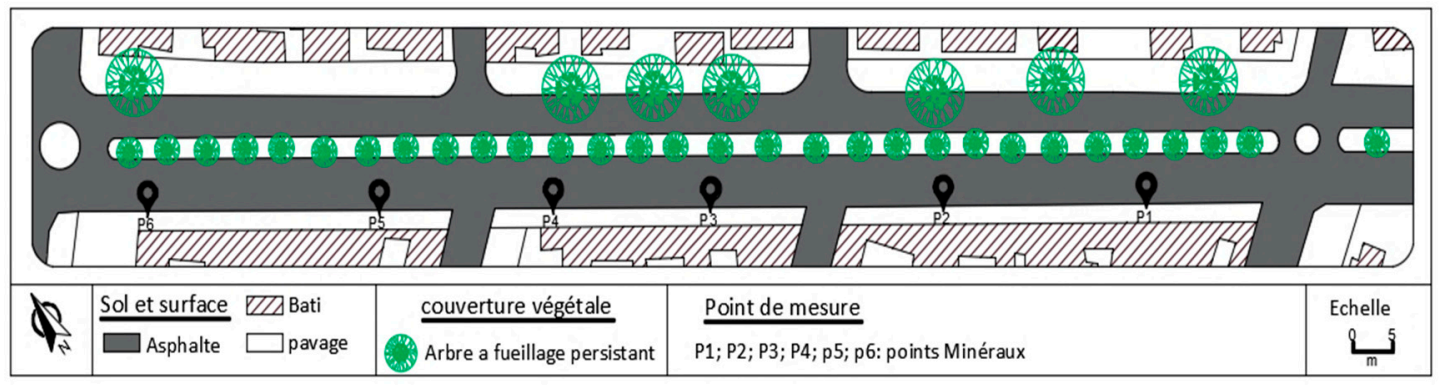

(c)

Figure 1. (a) Location of Guelma city; (b) Aerial view of Souidani Boudjemaa Boulevard; (c) Plan view of Souidani Boudjemaa Boulevard showing the measuring points.

\section{Methods and Materials}

The goal of this study is to improve outdoor thermal comfort in a boulevard in Guelma, Algeria during the summer by using vegetation parameterization. However, a numerical simulation is used to assess two major parameters: species and tree layout. First, microclimate data on a sunny summer day are collected. Second, real microclimate data are used in various simulations using the Envi-met atmospheric model.

\subsection{On-Site Measurements}

The measurement campaign was carried out within six measuring points devoted of vegetation within Souidani Boudjemaa Boulevard over three successive days, ranging from 20 July until 22 July 2019. As a result, a daily log consisting of six sessions from 9:00 a.m. to 9:00 p.m. of the three parameters, air temperature, relative humidity, and wind Velocity, was obtained.

The measurements were performed using two hand-held instruments, Figure 2 . The first (Testo 480-AG 501 1ST, 0563 4800) is a multifunction instrument equipped with intelligent digital probes, independently calibrated. The instrument was used as a thermohygrometer and as an anemometer in the following order:

- Measurement of air temperature and relative humidity carried out using a $\varnothing 12 \mathrm{~mm}$ probe, with a high resolution of 0.01 and an accuracy of $\pm 0.03 \% \mathrm{RH}$ and $\pm 0.2{ }^{\circ} \mathrm{C}(+15$ to $\left.+30{ }^{\circ} \mathrm{C}\right)$;

- Wind velocity measurement carried out using a $\varnothing 16 \mathrm{~mm}$ fan-assisted measuring probe (max. $960 \mathrm{~mm}$ scale) with an accuracy of $\pm 0.2 \mathrm{~m} / \mathrm{s}$. 


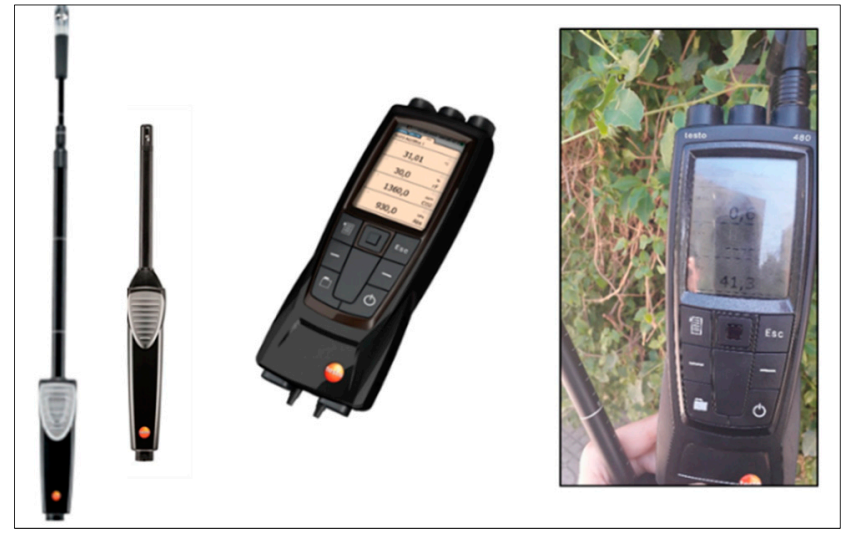

(a)

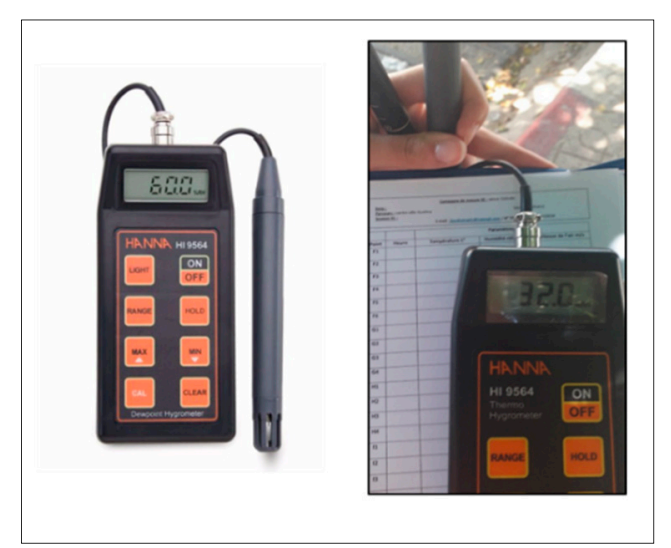

(b)

Figure 2. Measurement instruments: (a) Testo 480-AG 501 1ST, 0563 4800; (b) HENNA HI 9564.

The second instrument (HENNA HI + 9564) is a thermo-hygrometer, with a resolution of $0.1{ }^{\circ} \mathrm{C}$ and $0.1 \% \mathrm{RH}$ and an optimal precision of $\pm 0.5^{\circ} \mathrm{C}$ and $\pm 3 \% \mathrm{RH}$, and its role is to support the measurements temperature and humidity readings by Testo 480 .

\subsection{Atmospheric Simulation}

\subsubsection{The Simulation's Boundary Conditions}

An atmospheric simulation using the Envi-Met program is described in this study. This program requires input data, such as ratio, species, and tree layout, related to the Souidani Boudjemaa Boulevard's formal and vegetal composition. The Envi-met model's detailed framework and initial parameters are included in Table 1.

Table 1. Detailed framework and initial parameters of the Envi-met model (Envi-met V4.4.4).

\begin{tabular}{|c|c|c|}
\hline $\begin{array}{l}\text { Simulation's } \\
\text { settings }\end{array}$ & $\begin{array}{c}\text { City } \\
\text { Climate } \\
\text { Simulation Date } \\
\text { Simulation Time } \\
\text { UTCI index Calculation } \\
\text { Results visualization }\end{array}$ & $\begin{array}{c}\text { Guelma }\left(36^{\circ} 27^{\prime} 43 \mathrm{~N} ; 7^{\circ} 25^{\prime} 33 \mathrm{E} ; 840 \mathrm{ft}\right) \\
\text { Semi-arid } \\
\text { 22 July } 2019 \\
\text { From 09:00 to 21:00 } \\
\text { Biomet process } \\
\text { Leonardo plug-in }\end{array}$ \\
\hline \multirow{3}{*}{$\begin{array}{l}\text { Configuration's } \\
\text { model }\end{array}$} & Building & Concrete walls with roof tile \\
\hline & Soil and surface & $\begin{array}{c}\text { [PL] Concrete light } \\
\text { [ST] Asphalt road }\end{array}$ \\
\hline & Vegetation cover & $\begin{array}{l}\text { [BS] Very dense tree, } 12 \mathrm{~m} \text {, Albedo } 0.2 \\
\text { [T1] Dense tree, } 8 \mathrm{~m} \text {, Albedo } 0.2\end{array}$ \\
\hline
\end{tabular}

The microclimatic parameters resulting from the different simulations, i.e., air temperature $\left(T_{a}\right)$, relative humidity $(R H)$, mean radiant temperature $\left(T_{m r t}\right)$, and wind velocity $(\mathrm{WV})$, were used to study microclimatic variations, while the UTCI thermal index was used to measure the level of climatic comfort in each scenario, Figure 3.

\subsubsection{Generic Scenarios}

The 1st scenario simulates the present outdoor environment, including vegetation cover, in order to assess current thermal comfort level under summer heat stress, Figure 3a;

The 2nd scenario aimed to identify the impact of vegetation cover on outdoor thermal comfort, after which the simulation is run with the vegetation cover removed, Figure $3 b$;

The 3rd scenario is a simulation of the recent tree layout of Ficus Nitida species, Figure 3c; 
The 4th scenario simulates a new tree layout using the existing Ficus Benjamina tree species while maintaining the same tree ratio, Figure $3 \mathrm{~d}$;

The last scenario (5th situation) simulates a new tree layout for the boulevard, consisting of different kinds of Ficus Nitida and Washingtonia palm trees, Figure $3 \mathrm{e}$.

Tree species : Ficus benjamina Tree layout : aligned along the center

Ratio: 50 tree

(a)

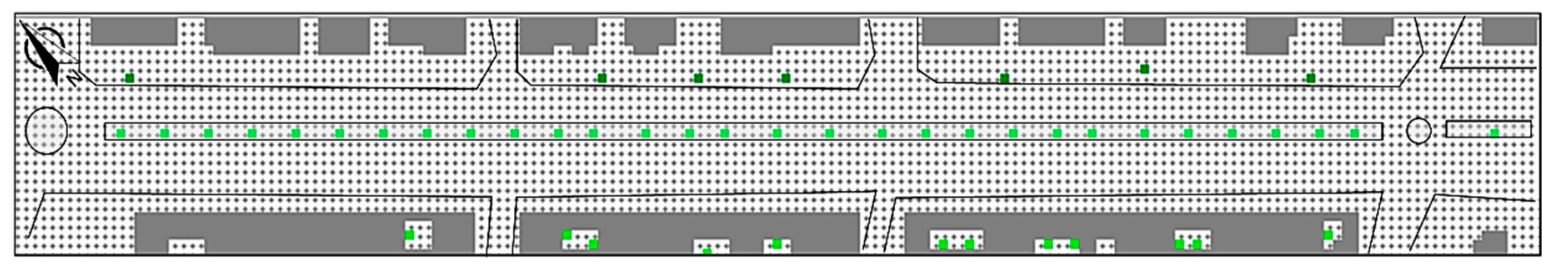

Tree species: // Tree layout : //

Ratio: //

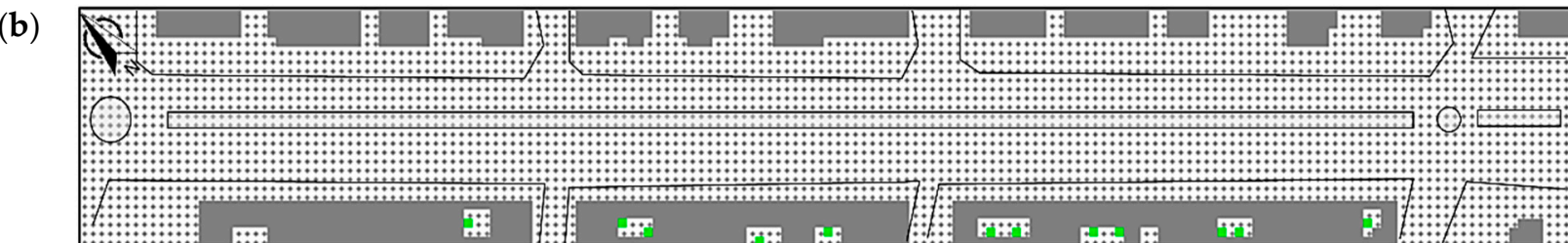

Tree species : Ficus nitida Tree layout : aligned along the center Ratio: 50 tree

(c)

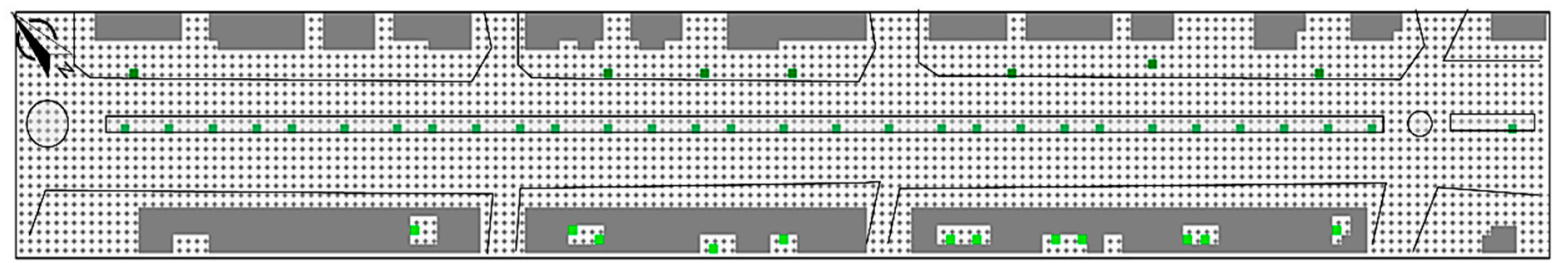

(d)

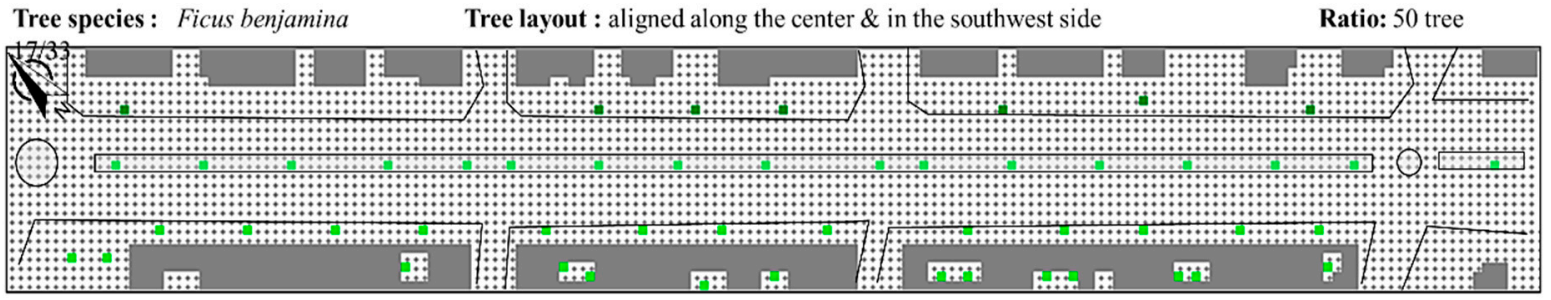

Tree species : Ficus benjamina \& washingtonia palms

Tree layout : aligned along the center \& in the southwest side

Ratio: 50 tree $17 / 33$

(e)

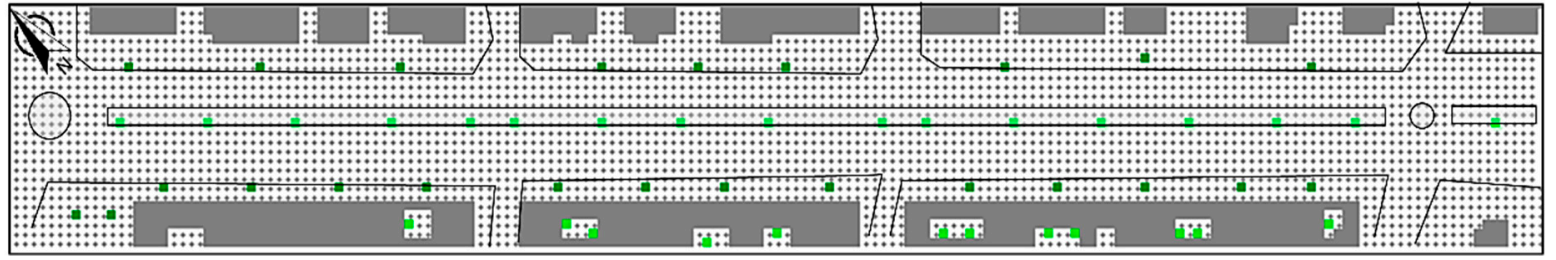

Figure 3. Simulated scenarios of Boulevard Souidani Boudjemaa: (a) the current state; (b) the boulevard stripped of vegetation; (c) new tree species; (d) new tree layout; and (e) new tree layout with a new tree species [Envi-met V4.4.4].

\section{Findings and Analysis}

\subsection{Atmospheric Model Validation}

In order to validate the Envi-Met model, the simulated values for the air temperature, relative humidity, and wind velocity were correlated with the values recorded in Souidani Boudjemaa Boulevard on 22 July 2019. Hence, the $\mathrm{R}^{2}$ is the reconciliation coefficient, indicating the degree of correlation. The results are presented in the graphs below, Figure $4 \mathrm{a}-\mathrm{c}$. 


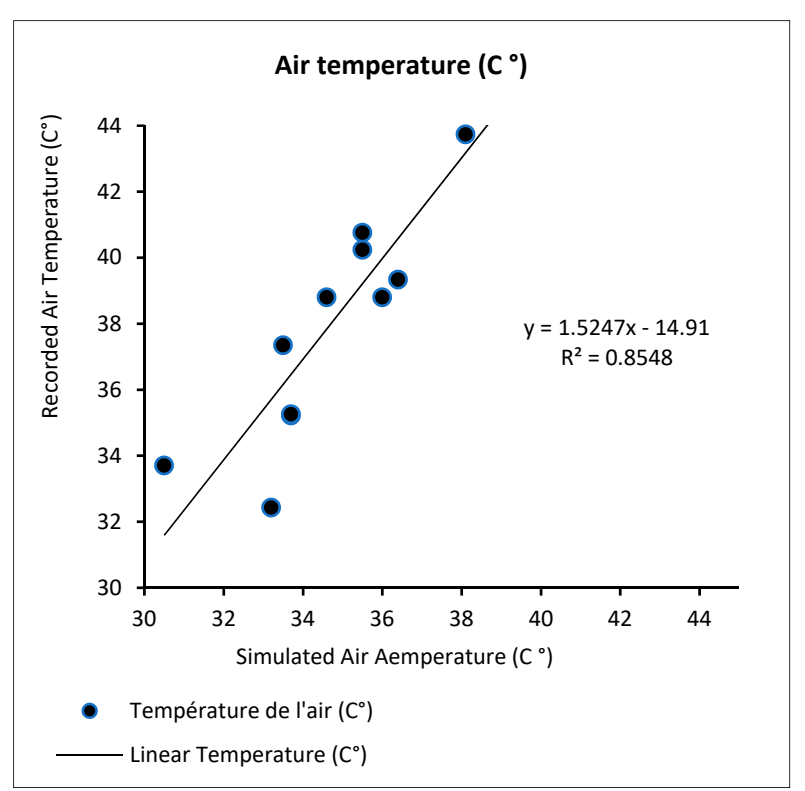

(a)

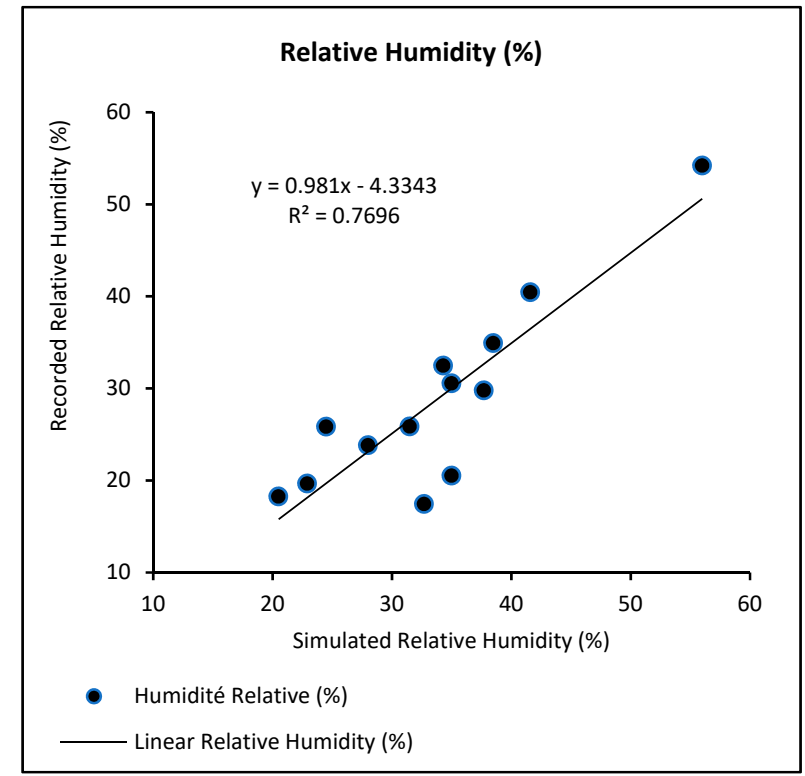

(b)

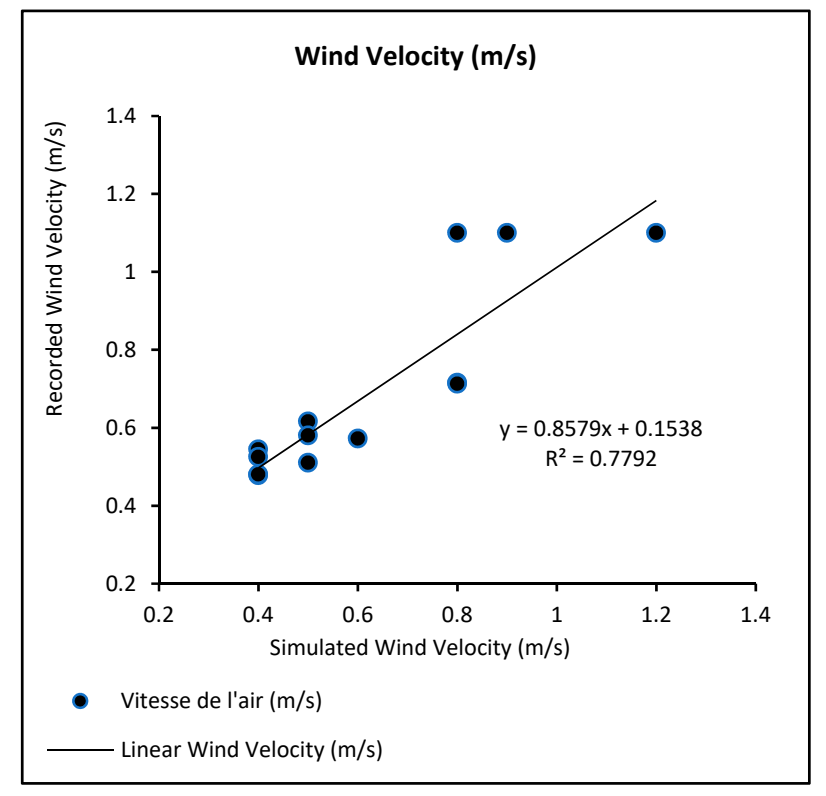

(c)

Figure 4. Validation of the Envi-Met simulation model, correlation of simulated and recorded values of: (a) air temperature; (b) relative humidity; and (c) wind velocity of Souidani Boudjemaa Boulevard.

We checked the correlation of the three parameters in two locations within the boulevard from 09:00 a.m. to 21:00 p.m. The reconciliation coefficients of the air temperature, relative humidity, and wind velocity are $R^{2}=0.85, R^{2}=0.76$, and $R^{2}=0.77$, respectively. All three indicate that the simulated values are strongly in agreement with the values recorded in downtown Guelma throughout the day of investigation, with a strong correlation of air temperatures.

In general, the model is capable of accurately reproducing the study context's climatic data, allowing for the evaluation of possibilities for enhancing thermal conditions by manipulating the formal and vegetal composition of Souidani Boudjemaa Boulevard. As a result, Envi-atmospheric Met's simulation model is suitable for achieving the study's aims. 


\subsection{Outdoor Thermal Comfort Optimization}

As aforementioned, the study involves the simulation of five different scenarios of Souidani Boudjemaa Boulevard, and the results are shown in the following graphs, Figure $5 \mathrm{a}-\mathrm{c}$. For all of the simulated scenarios, the general trend of air temperatures is ascending from 9:00 a.m. to 2:00 p.m. (peak time) and falling for post-peak hours. The relative humidity trend is in reverse order, where the peak time is set at 12:00 p.m. The overall trend of $\mathrm{T}_{\mathrm{mrt}}$ is similar to that of the UTCI index, which means that the thermal comfort outdoors is initially influenced by the received amount of solar radiation. In addition to wind velocity, evening hours from 8:00 p.m. reveal a certain stability for all of the parameters studied, including the UTCI index.

Scenario (2) revealed that removing the vegetation cover has a detrimental impact on microclimatic conditions. $\mathrm{T}_{\mathrm{mrt}}$ rose by $2.6^{\circ} \mathrm{C}$, with a maximum rise of $21^{\circ} \mathrm{C}$ at $17: 00$ a.m. The air temperature enhanced by $0.8^{\circ} \mathrm{C}$, with a maximum increase of $1.1^{\circ} \mathrm{C}$ at 3:00 p.m. At 12:00 p.m., the relative humidity had dropped to $17.2 \%$. In this situation, the greatest wind velocities were achieved. This indicates that the existing species and tree layout have altered the thermal conditions within the boulevard significantly.

Scenario (3) almost underwent a variation in air temperatures and relative humidity similar to that of Scenario (1), with a slight difference in wind velocities. The low $\mathrm{T}_{\mathrm{mrt}}$ values suggest that the tree species was able to block shortwave radiation while allowing longwave radiation to pass through its canopy, resulting in a reduction in heat stress and an increase in outdoor thermal comfort.

Changing the tree layout in Scenario (4) involves cast shadows positioned end to end, which maximizes the shaded area, especially during the afternoon period when the sun moves from south to west. This justifies the tangible reduction in the daily values of air temperatures $\left(-0.4{ }^{\circ} \mathrm{C}\right.$ at 1:00 p.m. and $-0.8^{\circ} \mathrm{C}$ at $6: 00$ p.m. $)$. Such a reduction with the increase in wind velocities is capable of providing a better level of climatic comfort compared to that provided in scenario (1) (the current boulevard), particularly in hot hours ( $\triangle \mathrm{UTCI}=1.8^{\circ} \mathrm{C}$ at 3:00 p.m.).

Scenario (5) implies a significant reduction in air temperatures $\left(\Delta \mathrm{Ta}_{\mathrm{avg}}=-1.2{ }^{\circ} \mathrm{C}\right.$ with $\Delta \mathrm{Ta}_{\max }=1.8^{\circ} \mathrm{C}$ at 4:00 p.m.), with relatively low values of $\mathrm{T}_{\mathrm{mrt}}$. This is mainly due to the ability of palm trees to block solar radiation and maximize the shaded area, as well as its long trunk facilitating the good circulation of air within the boulevard.

\subsection{Effect of Tree Species on Outdoor Thermal Comfort}

\subsubsection{Ficus Trees}

The species Ficus Nitida, inherited from the colonial era, has shown a strong ability to offer optimal climatic comfort levels in downtown Guelma, hence the dense and rounded canopy of mature Ficus trees constitute strategy of adaptation to the urban thermal environment by shading effect [16].

The Ficus Benjamina shares the same qualities of the Ficus Nitida with an average size and a smaller shade radius. The Benjamina species is established throughout the center of Souidani Boudjemaa Boulevard, characterized by a dense and rounded right canopy, still growing.

A drop in $T_{m r t}$ was seen when Ficus Benjamina tree species were replaced with Ficus Nitida trees, along with a small rise in the relative humidity. Both species provide shaded areas throughout the day, however, the difference in radiation at 2:00 p.m. shows that the retusa species is the most important in regulating heat exchange during hours of high heat, particularly heat exchange through radiation (Table 2). As a result, the dense and persistent leaf mass of the Nitida species successfully blocked shortwave radiation, leaving longwave radiation underneath its rounded and wide canopy over a shadow radius of more than $4 \mathrm{~m}$. 


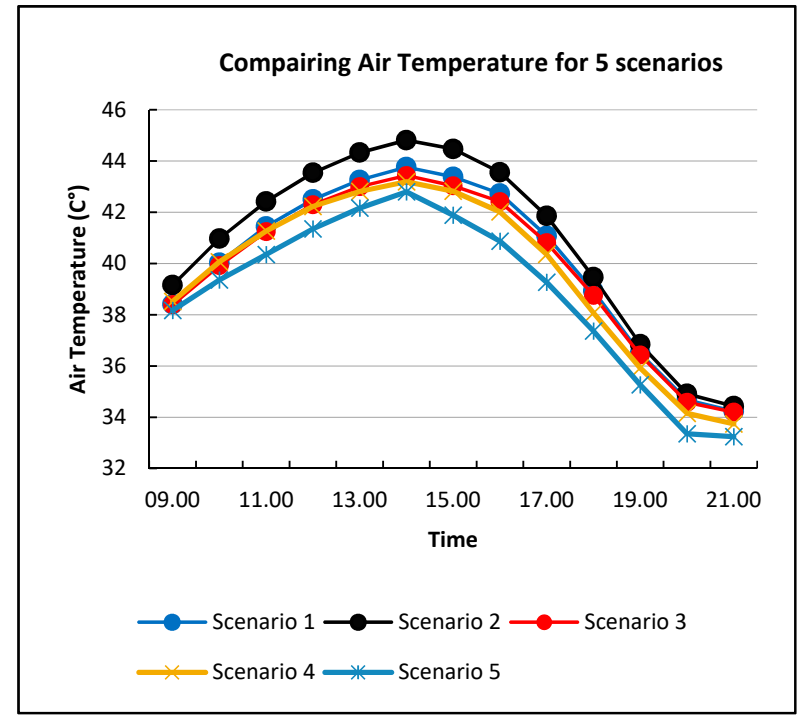

(a)

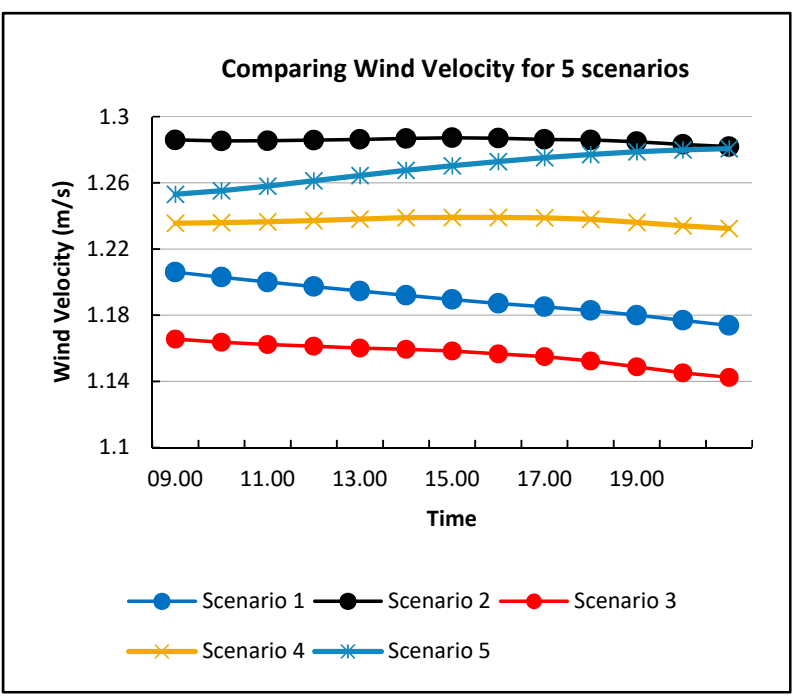

(c)

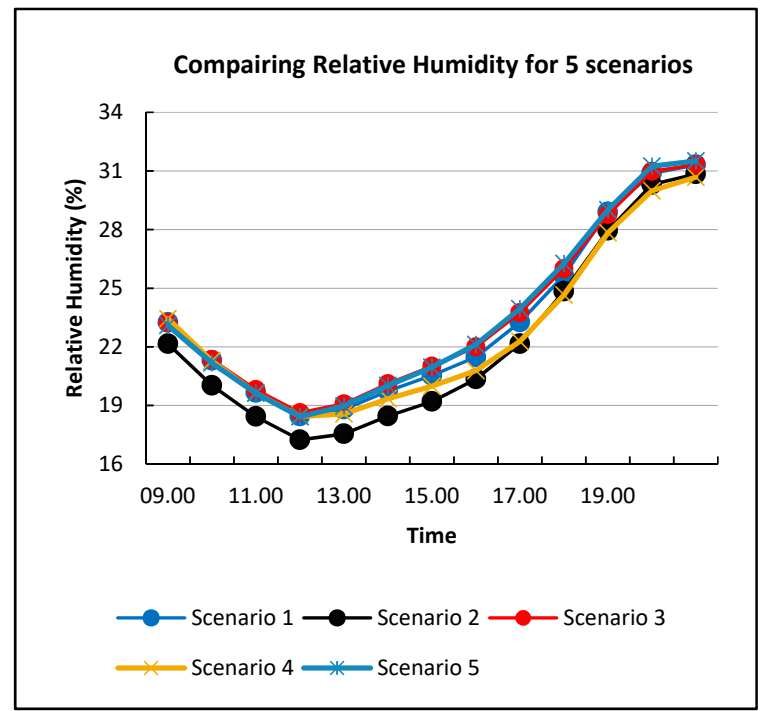

(b)

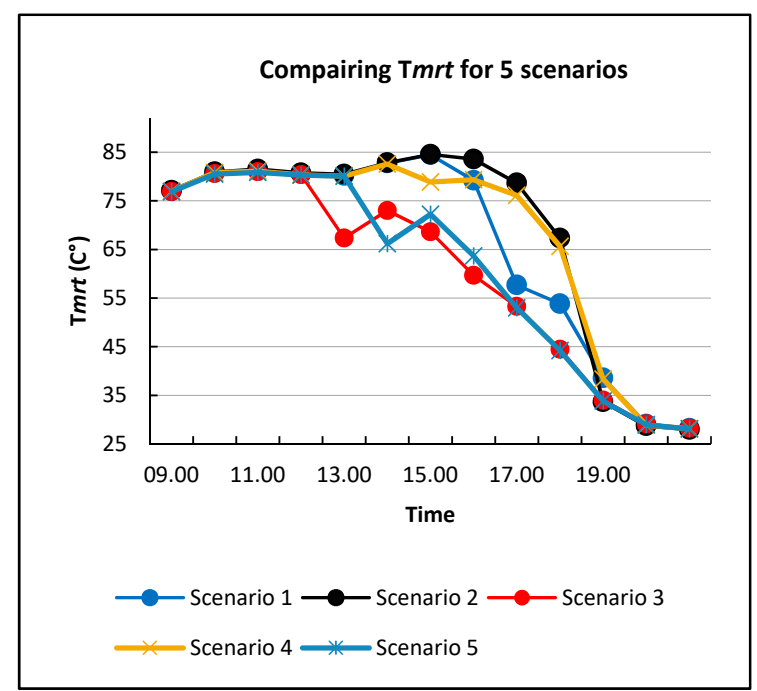

(d)

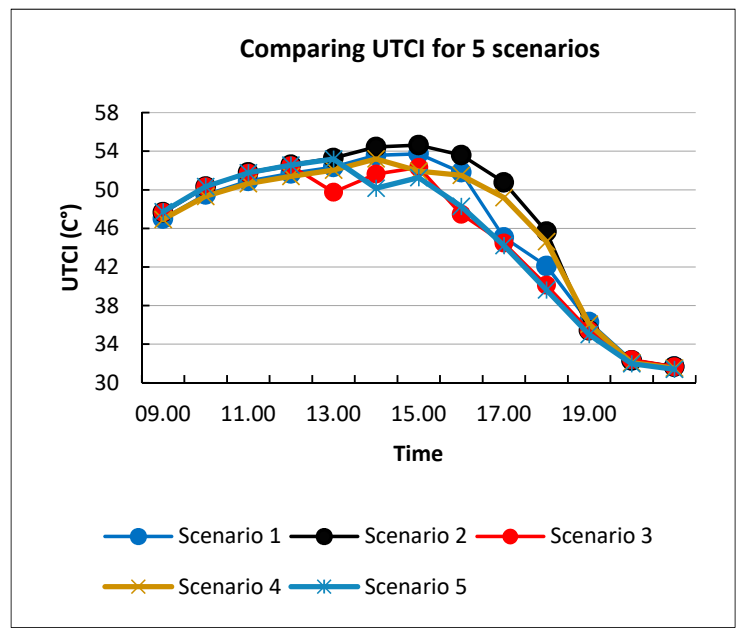

(e)

Figure 5. Comparing simulation results Souidani Boudjemaa Boulevard: (a) Air temperature; (b) Relative humidity; (c) Wind velocity; (d) Tmrt; (e) UTCI index. (Leonardo-Envi-Met 4). 
Table 2. Heat exchanges by radiation of trees in Souidani Boudjemaa Boulevard at 2:00 pm.

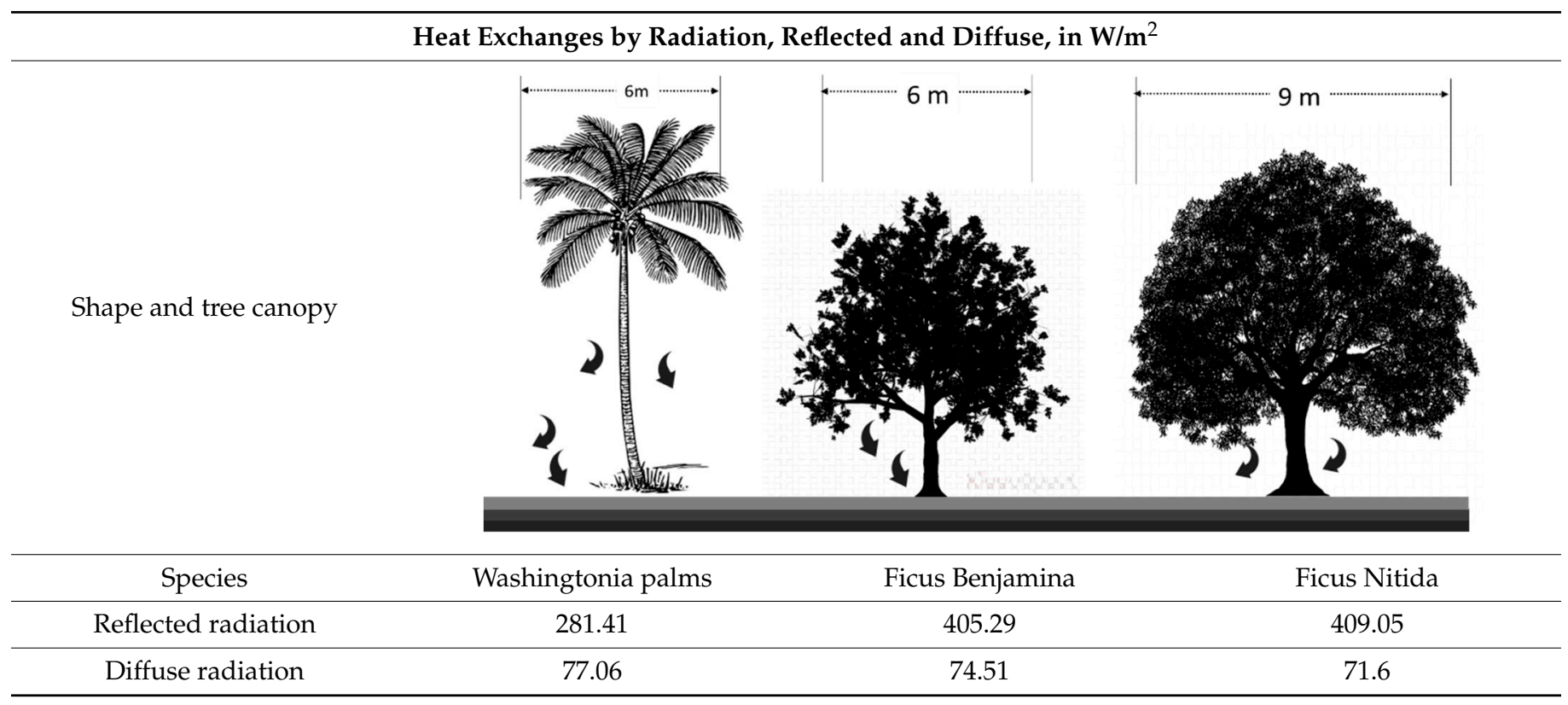

Due to its heavy appearance and massive character, the Ficus generates generally low wind speeds, creating an obstacle effect in the urban environment. This effect depends on the mass of the leaves. Indeed, a negligible difference was generated by the species Benjamina compared to Nitida.

\subsubsection{Palm Trees}

The Washingtonia species is abundantly planted in downtown Guelma, despite the dangers it poses to residential neighborhoods. Various plant compositions have been used in previous research to explore the microclimatic control function of palm plants. Palm trees have the same regulating function as other evergreen trees, however, they are not suited for semi-arid settings, according to the findings [37].

With regard to Souidani Boujemaa Boulevard, the Washingtonia Palms was introduced with its imposing vertical accent as a feature of the landscape throughout the center, with a ratio of 17 palms. Therefore, a significant reduction in air temperatures with relatively low values of $T_{m r t}$ was obtained. This is mainly due to the ability of palm trees to block solar radiation and control solar radiation exchanges.

In short, Washington Palm species affect microclimatic conditions by shading during heat stress and may improve microclimatic conditions by lowering outdoor temperatures. Hence, the diffuse radiation can reach $77.06 \mathrm{~W} / \mathrm{m}^{2}$.

\subsubsection{Effect of Tree Layout on Outdoor Thermal Comfort}

Sun position and wind direction are the two factors which indirectly influence the thermal outdoor comfort. However, sun position throughout the day is decisive for the quality of the shadows cast from the trees, although the hydrodynamic barrier effect of trees in outdoor spaces depends on the blow and direction of the prevailing winds.

\subsection{Effect of Tree Layout on Outdoor Thermal Comfort}

4.4.1. Hydrodynamic Obstruction Effect

Feeling the air flow is important to appreciate the quality of freshness in green outdoor spaces. Considering all the reasons that obstruct the air flow in outdoor spaces, including the massive shape of the trees, the feeling of the draft in summer becomes almost impossible. 
Based on this observation, much research has been carried out to make the sensation of air movement possible in urban areas during the summer while studying the physical characteristics of all kinds of obstacles, such as the position, morphology, and size of trees $[38,39]$. On our part, we have investigated the influence of the tree layout on air flow, which originates from the northwest in Souidani Boujemaa Boulevard.

The tree layout along Souidani Boudjemaa Boulevard constitutes a screen against the prevailing wind coming from the northwest, which serves as a windbreak in winter, Table 3.

Table 3. Wind velocity variation according to the tree layout in Souidani Boudjemaa Boulevard.

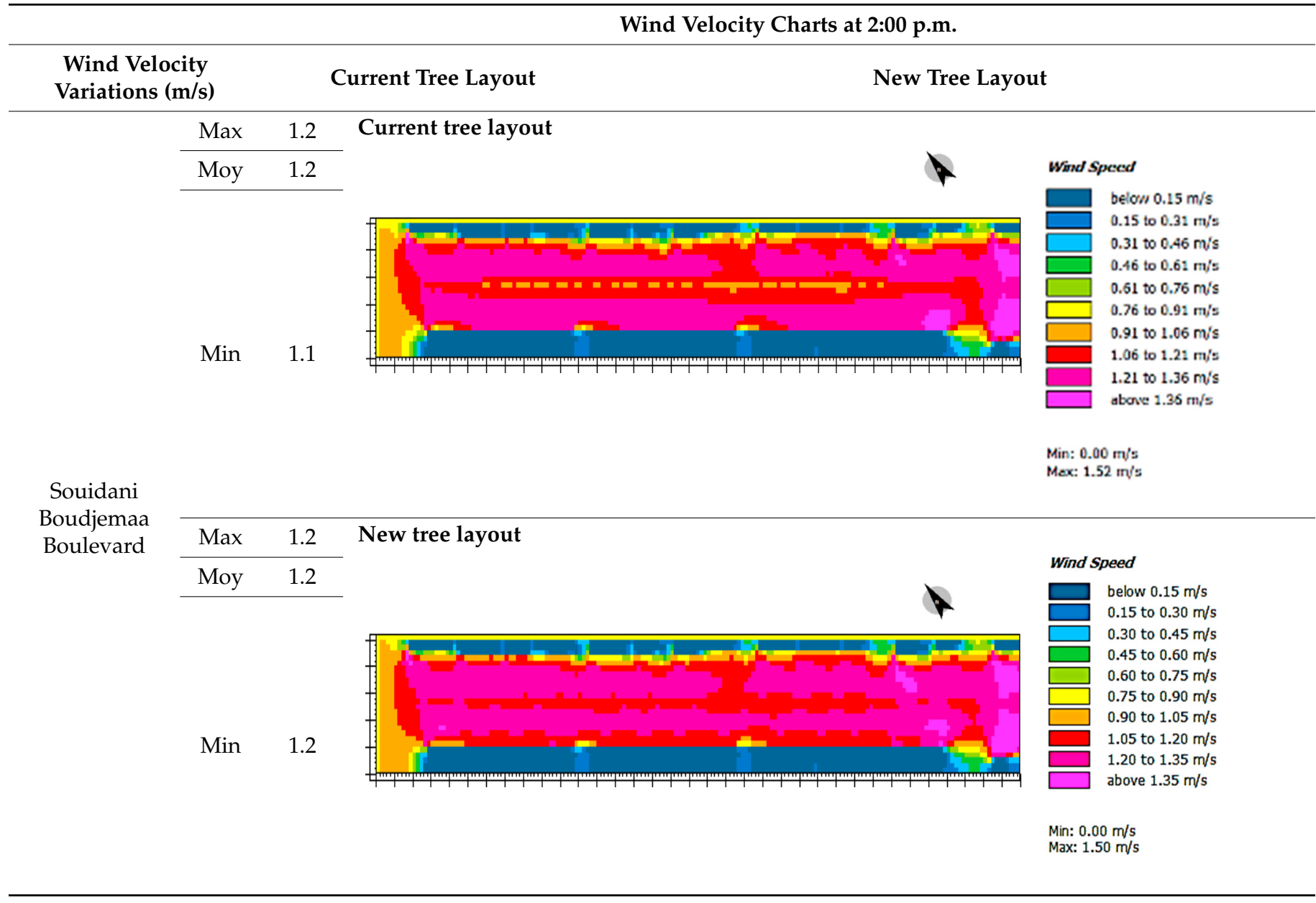

In addition, the effects of these shelterbelts on airflow in summer will increase as trees mature. Moving a third of the alignment trees to the southeast side of the boulevard generates both high air speeds along the center and slower speeds at the right aisle of the boulevard. It should be noted that the obstruction effect of trees planted first compared to the buildings of equal or larger size is negligible.

\subsubsection{Shading Effect}

Previous studies have demonstrated that the quality of the shadows cast by trees is decisive for the thermal comfort of users at the pedestrian level in summer. As the sun's position varies throughout the day, tree arrangements useful in the morning hours may no longer be the evening hours and vice versa.

The effect of the tree layout on outdoor thermal comfort in summer was apprehended by testing the current tree layout and another one with two types of trees at different sizes in Souidani Boudjemaa Boulevard. 
The alignment of trees located along the center of Souidani Boudjemaa Boulevard are on average 8 to $9 \mathrm{~m}$ in size and create shadows in the morning from 4 to $9.4 \mathrm{~m}$ and from 2.4 to 3.6 between 12:00 p.m. and 14:00 p.m. Shadows from 5.6 to $23.1 \mathrm{~m}$ in the afternoon are all projected onto the left lane of the boulevard. The right aisle of the boulevard is entirely devoid of trees, which directly exposes the straight lane to the blazing hot sun from 10:00 a.m. to 2:00 p.m. The new tree layout implies the relocation of a third of the alignment's trees to the southwest side of the boulevard, which involves drop shadows positioned end to end. This helps to create shady paths along the boulevard, especially during the afternoon period when the sun moves from south to west, the length of the shadows depending on the size of the trees (Table 4).

Table 4. Quality of the shadow cast depending on the tree layout in Souidani Boudjemaa Boulevard.

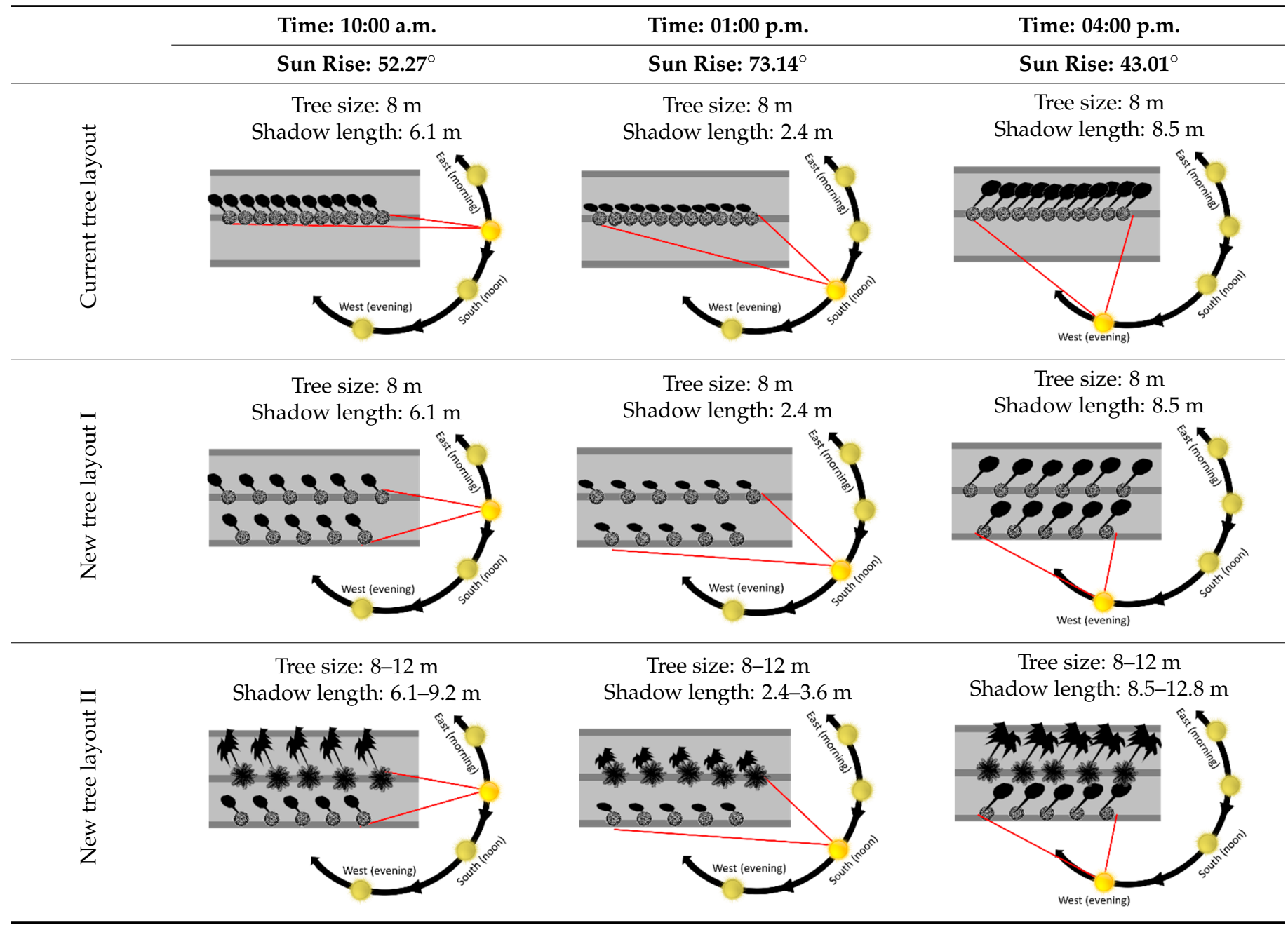

\subsection{Limitations}

In the present study, the outdoor of thermal comfort optimization was reached through two plant parameters and three microclimatic parameters to simulate different configurations of natural elements at Souidani Boudjemaa Boulevard, while others could lead to precise results in providing the required comfort in hot summer situations. At this stage, it would be useful to look for optimal comfort levels by calculating the skey view factor, which relates the vegetation to the amount of received solar radiation. 


\section{Conclusions}

This study investigates the outdoor thermal comfort optimization through the parameterization of urban trees in Guelma city, Algeria during the summertime. However, two main parameters were investigated, species and tree layout of Souidani Boudjemaa boulevard, through a numerical simulation. In general, the results indicate that urban trees can improve the thermal comfort levels in summer through shading effect, which is controlled by a set of parameters related to the physical characteristics of trees and their location outdoors. Trees can also cool the ambient environment by the evapotranspiration effect, which depends on the first level of tree foliage, its mass, and its texture. Indeed, the highest relative humidity has been recorded, largely in trees with smooth foliage. The tree species is the first parameter influencing shade quality. Due to its rounded canopy and dense leaf mass, Ficus Nitida is the most significant species to intercept solar radiation and provide shade over the day in Souidani Boudjemaa Boulevard. The tree layout is a determining parameter in the creation of shaded paths, based on the quality of the shadows cast by the trees, namely, their size. Thereby, planting the Washingtonia palm trees along the center of the boulevard is the best option to maximize the shaded area within the boulevard. The tree layout is also decisive for the air flow in the outdoor spaces, where it is advisable that the trees are not planted against the northwesterly blast of the wind.

Author Contributions: Conceptualization, B.S. and D.A.; methodology, R.R. and H.A.; software, B.S. and M.I.; validation, Y.M. and M.S.; formal analysis, G.L.; investigation, B.S. and R.R.; resources, D.A. and H.A.; data curation, M.I. and Y.M.; Funding, E.A. and A.Y.E.; writing-original draft preparation, M.S. and G.L.; writing-review and editing, E.A., A.Y.E. and Y.M. All authors have read and agreed to the published version of the manuscript.

Funding: This research is funded by Taif University Researchers Supporting Project Number (TURSP2020/32), Taif University, Taif, Saudi Arabia.

Institutional Review Board Statement: Not applicable.

Informed Consent Statement: Not applicable.

Data Availability Statement: All data is available in manuscript.

Acknowledgments: We thank Taif University Researchers Supporting Project Number (TURSP2020/32), Taif University, Taif, Saudi Arabia.

Conflicts of Interest: The authors declare no conflict of interest.

\section{References}

1. United Nations. $68 \%$ of the World Population Projected to Live in Urban Areas by 2050, Says UN. Available online: https: //www.un.org/development/desa/en/news/population/2018-revision-of-world-urbanization-prospects.html (accessed on 6 February 2021).

2. Nuruzzaman, M. Urban Heat Island: Causes, Effects and Mitigation Measures-A Review. Int. J. Environ. Monit. Anal. 2015, 3, 67-73. [CrossRef]

3. Hammadi, T. The role of urban landscape design in enhancing people's outdoor places and spaces. Int. J. Adv. Res. 2017, 5, 1084-1099. [CrossRef]

4. Sayad, B.; Alkama, D.; Rebhi, R.; Kidar, A.; Lorenzini, G.; Ahmad, H.; Menni, Y. Enhanced Outdoor Thermal Comfort Through Natural Design Technique: In-Situ Measurement and Microclimate Simulation. Instrum. Mes. Métrol. 2021, 20, 131-136. [CrossRef]

5. Bandurski, K.; Bandurska, H.; Kazimierczak-Grygiel, E.; Koczyk, H. The Green structure for outdoor places in dry, hot regions and seasons-Providing HUMAN THERMAL COMFORT in sustainable Cities. Energies 2020, 13, 2755. [CrossRef]

6. Kamel, T.M. A new comprehensive workflow for modelling outdoor thermal comfort in Egypt. Sol. Energy 2021, $225,162-172$. [CrossRef]

7. Altunkasa, C.; Uslu, C. Use of outdoor microclimate simulation maps for a planting design to improve thermal comfort. Sustain. Cities Soc. 2020, 57, 102137. [CrossRef]

8. Lee, V.; Zermoglio, F.; Ebi, K.L. Heat Waves and Human Health Emerging Evidence and Experience to Inform Risk Management in a Warming World; Technical Report; United States Agency for International Development USAID: Washington, DC, USA, 2019. Available online: https:/ / www.climatelinks.org/projects/atlas (accessed on 13 February 2019).

9. Grassi, B.; Piana, E.A.; Beretta, G.P.; Pilotelli, M. Dynamic approach to evaluate the effect of reducing district heating temperature on indoor thermal comfort. Energies 2021, 14, 25. [CrossRef] 
10. Kwon, Y.J.; Lee, D.K.; Lee, K. Determining favourable and unfavourable thermal areas in seoul using in-situ measurements: A preliminary step towards developing a smart city. Energies 2019, 12, 2320. [CrossRef]

11. Lam, C.K.C.; Gao, Y.; Yang, H.; Chen, T.; Zhang, Y.; Ou, C.; Hang, J. Interactive effect between long-term and short-term thermal history on outdoor thermal comfort: Comparison between Guangzhou, Zhuhai and Melbourne. Sci. Total Environ. 2021, 760, 144141. [CrossRef]

12. Moreno-Rangel, A.; Sharpe, T.; McGill, G.; Musau, F. Thermal comfort assessment of the first residential Passivhaus in Latin America. J. Build. Eng. 2021, 43, 103081. [CrossRef]

13. Xie, Y.; Niu, J.; Zhang, H.; Liu, S.; Liu, J.; Huang, T.; Li, J.; Mak, C.M. Development of a multi-nodal thermal regulation and comfort model for the outdoor environment assessment. Build. Environ. 2020, 176, 106809. [CrossRef]

14. Lai, D.; Liu, W.; Gan, T.; Liu, K.; Chen, Q. A review of mitigating strategies to improve the thermal environment and thermal comfort in urban outdoor spaces. Sci. Total Environ. 2019, 661, 337-353. [CrossRef]

15. Gachkar, D.; Taghvaei, S.H.; Norouzian-Maleki, S. Outdoor thermal comfort enhancement using various vegetation species and materials (case study: Delgosha Garden, Iran). Sustain. Cities Soc. 2021, 75, 103309. [CrossRef]

16. Sayad, B.; Alkama, D. A combined approach to predict the human thermal comfort in downtown Guelma-Algeria. Int. J. Innov. Stud. Sociol. Humanit. 2021, 6, 1-14.

17. Sayad, B.; Alkama, D.; Ahmad, H.; Baili, J.; Aljahdaly, N.H.; Menni, Y. Nature-based solutions to improve the summer thermal comfort outdoors. Case Stud. Therm. Eng. 2021, 28, 101399. [CrossRef]

18. Coccolo, S.; Paoli, M.D.; Stracqualursi, A.; Andreucci, M.B. Design the urban microclimate: Nature-based solutions and technology at nexus. In Urban Services to Ecosystems. Future City; Catalano, C., Andreucci, M.B., Guarino, R., Bretzel, F., Leone, M., Pasta, S., Eds.; Springer: Cham, Switzerland, 2021; Volume 17. [CrossRef]

19. Susca, T. Nature-based solutions applied to the built environment to alleviate climate change: Benefits, co-benefits, and trade-offs in a geographical multi-scale perspective. In Handbook of Climate Change Mitigation and Adaptation; Gabler: Wiesbaden, Germnay, 2021; pp. 1-52.

20. Yilmaz, S.; Mutlu, B.E.; Aksu, A.; Mutlu, E.; Qaid, A. Street design scenarios using vegetation for sustainable thermal comfort in Erzurum, Turkey. Environ. Sci. Pollut. Res. 2021, 28, 3672-3693. [CrossRef] [PubMed]

21. Meili, N.; Acero, J.A.; Peleg, N.; Manoli, G.; Burlando, P.; Fatichi, S. Vegetation cover and plant-trait effects on outdoor thermal comfort in a tropical city. Build. Environ. 2021, 195, 107733. [CrossRef]

22. Fabbri, K.; Ugolini, A.; Lacovella, A.; Bianchi, P. The effect of vegetation in outdoor thermal comfort in archaeological area in urban context. Build. Environ. 2020, 175, 106816. [CrossRef]

23. Yang, W.; Lin, Y.; Li, C.-Q. Effects of Landscape Design on Urban Microclimate and Thermal Comfort in Tropical Climate. Adv. Meteorol. 2018, 2018, 1-13. [CrossRef]

24. Wang, Y.; Bakker, F.; De Groot, R.; Wortche, H.J.; Leemans, R. Effects of urban trees on local outdoor microclimate: Synthesizing field measurements by numerical modelling. Urban Ecosyst. 2015, 18, 1305-1331. [CrossRef]

25. Ridha, S.; Ginestet, S.; Lorente, S. Effect of the shadings pattern and greenery strategies on the outdoor thermal comfort. Int. J. Eng. Technol. 2018, 10, 108-114. [CrossRef]

26. Huang, Z.; Wu, C.; Teng, M.; Lin, Y. Impacts of tree canopy cover on microclimate and human thermal comfort in a shallow street canyon in Wuhan, China. Atmosphere 2020, 11, 588. [CrossRef]

27. Zare, S.; Hasheminejad, N.; Shirvan, H.E.; Hemmatjo, R.; Sarebanzadeh, K.; Ahmadi, S. Comparing universal thermal climate index (UTCI) with selected thermal indices/environmental parameters during 12 months of the year. Weather Clim. Extrem. 2018, 19, 49-57. [CrossRef]

28. Staiger, H.; Laschewski, G.; Matzarakis, A. Selection of appropriate thermal indices for applications in human biometeorological studies. Atmosphere 2019, 10, 18. [CrossRef]

29. Fang, Z.; Zhang, Y.; Yang, Y.; Zhou, X.; Zheng, Z. Experimental investigation of standard effective temperature (SET*) adapted for human walking in an indoor and transitional thermal environment. Sci. Total Environ. 2021, 793, 148421. [CrossRef]

30. Sharmin, T.; Steemers, K.; Humphreys, M. Outdoor thermal comfort and summer PET range: A field study in tropical city Dhaka. Energy Build. 2019, 198, 149-159. [CrossRef]

31. Ghiai, M.M.; Arjmand, J.T.; Mohammadi, O.; Ahmadi, M.H.; Assad, M.E.H. Investigation and modeling of energy consumption of tall office buildings in Iran 'shot-arid' and cold' climate conditions. Int. J. Low Carbon Technol. 2021, 16, 21-34. [CrossRef]

32. Esbati, S.; Amooie, M.A.; Sadeghzadeh, M.; Ahmadi, M.H.; Pourfayaz, F.; Ming, T. Investigating the effect of using PCM in building materials for energy saving: Case study of Sharif Energy Research Institute. Energy Sci. Eng. 2019, 8, 959-972. [CrossRef]

33. Alayi, R.; Ahmadi, M.H.; Visei, A.R.; Sharma, S.; Najafi, A. Technical and environmental analysis of photovoltaic and solar water heater cogeneration system: A case study of Saveh City. Int. J. Low Carbon Technol. 2021, 16, 447-453. [CrossRef]

34. Vakilabadi, M.A.; Afzalabadi, A.; Poorfar, A.K.; Rahbari, A.; Bidi, M.; Ahmadi, M.H.; Ming, T. Technical and economical evaluation of grid-connected renewable power generation system for a residential urban area. Int. J. Low Carbon Technol. 2019, 14, 10-22. [CrossRef]

35. Khoshbazan, M.; Ahmadi, M.H.; Ming, T.; Arjmand, J.T.; Rahimzadeh, M. Thermo-economic analysis and multi-objective optimization of micro-CHP Stirling system for different climates of Iran. Int. J. Low Carbon Technol. 2018, 13, 388-403. [CrossRef]

36. Belda, M.; Holtanová, E.; Halenka, T.; Kalvová, J. Climate classification revisited: From Köppen to Trewartha. Clim. Res. 2014, 59, 1-13. [CrossRef] 
37. Sayad, B.; Alkama, D. Microclimatic regulation of palm trees in semi-arid environment during heat stress. J. Fundam. Appl. Sci. 2021, 13, 694-707.

38. Matzarakis, A.; Mayer, H. Atmospheric conditions and human thermal comfort in urban areas. In Proceedings of the 11th Seminar on Environmental Protection, Environment and Health, Thessaloniki, Greece, 20-23 November 2000; pp. 155-166.

39. Sayad, B.; Alkama, D. Study of the microclimate behavior in spaces between buildings: Which strategy to adopt during cold season in Guelma's public SPACES? Xiamen-Custipen Workshop on the Equation of State of Dense Neutron-Rich Matter in the Era of Gravitational Wave Astronomy. AIP Conf. Proc. 2019, 2123, 30007. [CrossRef] 